\title{
A critical review on ultra high molecular weight polyethylene (UHMWPE) for prosthesis and implant functions
}

\author{
Devendra Kumar Singh ${ }^{1}$, Rajesh Kumar Verma ${ }^{2 *}$ \\ 1,2 Materials \& Morphology Laboratory, Department of Mechanical Engineering, Madan Mohan Malaviya University of Technology, \\ Gorakhpur- 273010, India
}

\begin{abstract}
Polymer composites benefit joint prostheses and implants in biomaterials due to their high strength, reliability, and elasticity modules. The addition of nanoparticles into the polymer-based matrix has effectively demonstrated up-grading wear resistance and implant strength improvement. Therefore, due to the elevated surface area and immense properties, considerable attention has been paid to research in integrating nanoparticles for a wide variety of functions. The UHMWPE is extensively used to develop prosthesis and orthopedic operations due to exceptional mechanical and biocompatible features. The various research studies revealed the fabrication of bio nanocomposites with the polymer matrix possesses superior biocompatibility and durability. This paper presents a critical review of UHMWPE for the latest advancement in polymeric implants by adding different nanoparticles. Another exciting aspect of the proposed work is the addition of different organic (carbon, polymeric) and inorganic (metallic and metal oxides) nanoparticles to develop bio-nano composites. An effort has been made to highlight the exceptional features of modified UHMWPE by supplementing nanofillers for biomedical functions.
\end{abstract}

\section{Introduction}

Polymeric materials are widely used for the function of lightweight and durability in manufacturing industries. Due to its improved mechanical and chemically resistive features, it is actively used in bio-nano composites. The heavyweight and costly metallic prosthetic implants are effectively substituting by biopolymeric materials. The hip joint is the most pivoted point to bear the whole body weight during a moment, and it joins the femurs to the pelvis. It consists of a spherical and smooth head that perfectly matches the natural cup-shaped cavity called the acetabulum cup. This joint is vulnerable to excessive daily routine stresses. The hip joint takes the load of the upper half of the body parts. These stresses put the joint at risk, particularly with advancing age and sports activities. Thus, total joint arthroplasty treatments are an essential concern[1], [2]. Extensive research in this field shows a high success rate, but the implants' longevity remains a limiting factor. The outstanding biocompatability and mechanical properties of UHMWPE marks it as an ideal bearing material for implants having optimum clinical and tribological outcomes [3]-[6].

The initial state of art demonstrates the feasibility of UHMWPE in biopolymers. But the present studies on the addition of nanomaterials in polymers are passing through the initial stage. It requires more attention from the manufacturing sector and academia. The literature shows that mechanical loosening, complications, infections and instability find their origin in osteolysis occurs due to polyethylene wear debris from a linear acetabular cup[2], [7]. This article highlights the emerging trend in the area of nanomaterial and UHMWPE. An attempt has been made to emphasize the importance of the biopolymer application in the medical field.

\section{Developments}

\subsection{Ultra-high molecular weight polyethylene}

UHMWPE is recorded by the international standards organization (ISO) as a polymer having a molecular weight of 1 million gram per mole with degree of polymerization of 36,000 . It is a semi-crystalline polymer with fully amorphous and crystalline phases [8]. while the American Society for Testing and Materials (ASTM) states that UHMWPE has a molecular weight of more than 3.1 million $\mathrm{g} /$ mole and a degree of polymerization of 110,000 .[9]

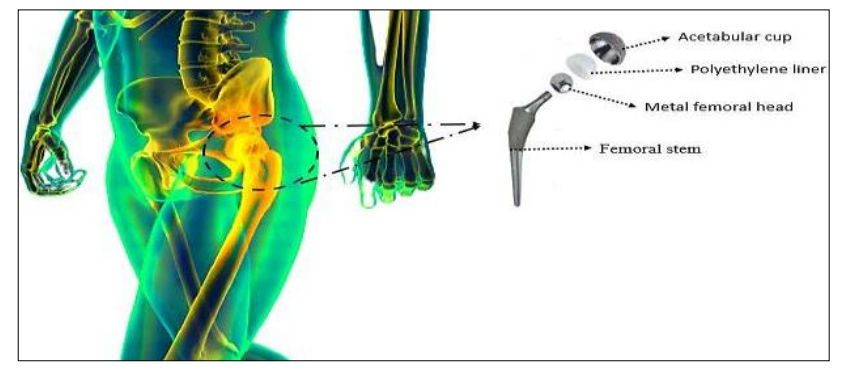


Fig.1. General pictorial view of the hip implant and its different components.

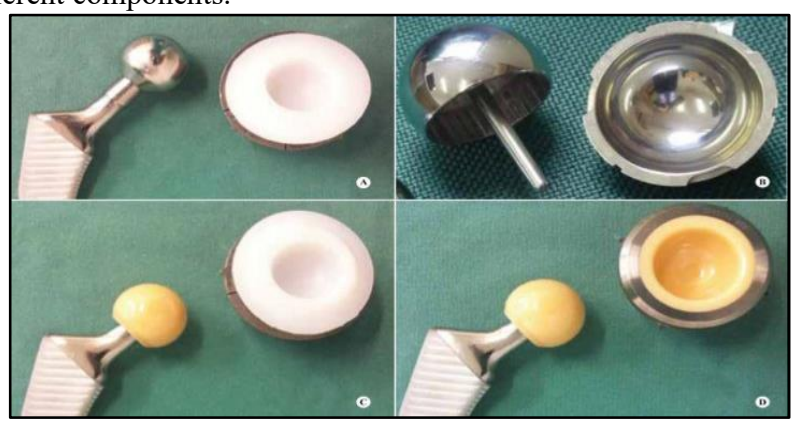

Fig.2. Different surfaces adopted in Hip joint replacement [10]

Table 1. Average properties HDPE and UHMWPE.[11]

\begin{tabular}{|l|c|c|}
\hline \multicolumn{1}{|c|}{ Property } & HDPE & UHMWPE \\
\hline Specific gravity & $0.952-0.965$ & $0.925-0.945$ \\
\hline $\begin{array}{l}\text { Molecular weight } \\
\left(10^{6} \mathrm{~g} / \mathrm{mol}\right)\end{array}$ & $0.05-0.25$ & $3.5-7.5$ \\
\hline $\begin{array}{l}\text { Melting of } \\
\left.\text { temp. }{ }^{\circ} \mathrm{C}\right)\end{array}$ & $130-137$ & $132-138$ \\
\hline $\begin{array}{l}\text { Modulus of } \\
\text { elasticity (GPa) }\end{array}$ & $0.4-4.0$ & $0.5-0.8$ \\
\hline $\begin{array}{l}\text { Degree of } \\
\text { rrystallinity (\%) }\end{array}$ & $60-80$ & $39-75$ \\
\hline $\begin{array}{l}\text { Tensile yield } \\
\text { strength (MPa) }\end{array}$ & $26-33$ & $22-28$ \\
\hline $\begin{array}{l}\text { Wear Rate (mm }{ }^{3} \\
/ 10^{6} \text { cycles) }\end{array}$ & $380-400$ & $80-100$ \\
\hline $\begin{array}{l}\text { Tensile ultimate } \\
\text { strength (MPa) }\end{array}$ & $22-31$ & $39-48$ \\
\hline $\begin{array}{l}\text { Impact strength } \\
(\mathrm{J} / \mathrm{m} \text { of the notch) }\end{array}$ & $21-214$ & 1070 \\
\hline
\end{tabular}

Table 1. describe the distinctive properties of UHMWPE and HDPE.one of the most mutual couples used in the hip implant is Metal-on-Plastic (MoP), which consists of cobalt-chromium (CoCr)alloy and UHMWPE femoral head as an acetabular liner. Fig.1 represents the general idea of the hip implant with its various components. Including femoral head sliding in polymer liner. Further different types of joints commonly adopted for hip replacement surgery can be best understood from Fig.2 (A) metal-to-polyethylene (B) metal-to-metal (C) ceramic-to-polyethylene (D) ceramic-to-ceramic. The primary concern in such implants is UHMWPE liner wear. Wear debris triggers bone resorption, aseptic loss, and implant failure. Some pictures of the degraded liner are shown in Fig.3 to develop a clearer picture of wear's form and magnitude. The following Fig.3 from (a-d) represents a) Highly oxidized liners with extensive rim cracks (b) Multiple subsurface rim cracks, (c) Shows liner modified after completed mechanical failure and (d) represents extensive cracking and separation of the rim. Also, the wear phenomenon can be better understood by Fig.4.

\subsection{UHMWPE modification}

The limitations of virgin UHMWPE as a biomaterial are due to its low melting point $\left(130{ }^{\circ} \mathrm{C}\right.$ to $\left.136{ }^{\circ} \mathrm{C}\right)$, the formation of free radicals because of gamma irradiation, and high wear rate. It can be reduced by reinforcing carbon, vitamin E (a type of antioxidant), and highly crosslinking, respectively. An increase in the lifetime of implants and can be achieved by increasing wear resistance and toughness. Crosslinking of the polymer with gamma irradiation is a very well tool for achieving enhanced wear resistance. Polymer crosslinking via gamma irradiation is a well-known solution to improve wear resistance, yet it inevitably leads to polymer oxidation. Extensive research is going on developing wear-resistant models with UHMWPE, out of which crosslinking in UHMWPE is one of the most efficient ways since the 1990s [13]. Jones et al. suggested robust confirmation of clinical advantage using highly crosslinked polyethylene (HXLPE) pertain to conventional UHMWPE. When compared to conventional UHMWPE, they revealed that HXLPE has a $40 \%$ reduced wear rate [14], [15]. While the clinical results on HXLPE are outstanding, problems pertaining to strength as well as crosslink stability persist. It is recognized that incorporation with vitamin $\mathrm{E}$ works as antioxidant decreases this without a significant loss of mechanical properties.
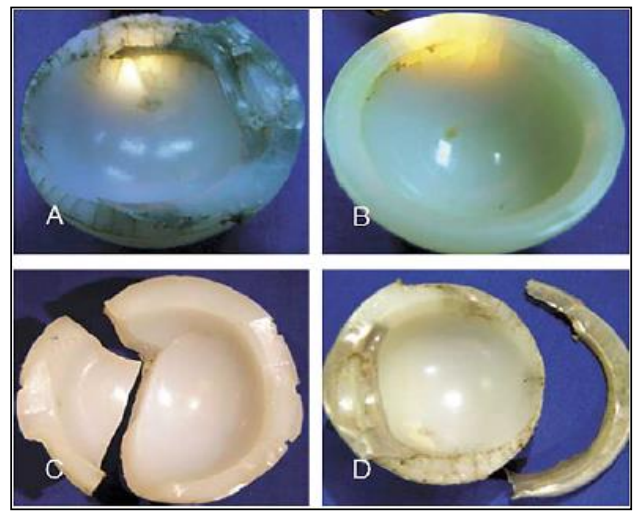

Fig.3. Different modes of UHMWPE liner failure while articulating with femur head [12]

The second solution is based on reinforcing reinforcements to the polymer to improve its tribological performance [16] [17]. While the clinical results on HXLPE are outstanding, problems pertaining to strength as well as crosslink stability persist. A new trend in UHMWPE includes the inclusion of Vitamin $\mathrm{E}$ is remarked for the development of vitamin E-doped crosslinked polyethylene VEHXLPE. Vitamin E, i.e., $\alpha-$ tocopherol-stabilized VEHXLPE incorporates the mechanical properties and reliability as traditional UHMWPE but shows reduced wear. Results from in vitro studies reveal that VEHXLPE has enhanced strength over HXLPE. The mechanical properties of VEHXLPE in comparison to UHMWPE are superior to UHMWPE with a lower wear rate[18]. Free radical scavengers such as Vitamin E helps to Stables the polymer from oxidative degradation in vivo. This is important since free radical production and subsequent oxidative degradation of UHMWPE can be caused by lipid adsorption [19].

Roeder et al. by assembling the information from different studies on biomaterial implants using a concept of Ashby or bubble chart. It is a type of bubble chart representing a dispersed plot with varying properties of materials or groups of materials. Fig. 5 depicts that the 
mechanical properties of the cortical bone and the UHMWPE are surprisingly close in the given diagram[20]. The thermal treatment has been proposed to dispose of residual free radicals or recombine the free radicals in place of irradiation and thus improve the oxidation obstruction. But, different remelting treatments may diminish UHMWPE crystallinity and its mechanical properties [21]. Studies have shown that the wear of crosslinked UHMWPE and the crosslinked UHMWPE- antioxidant agent have been improved in contrast with the utilization of traditional UHMWPE [22][23].

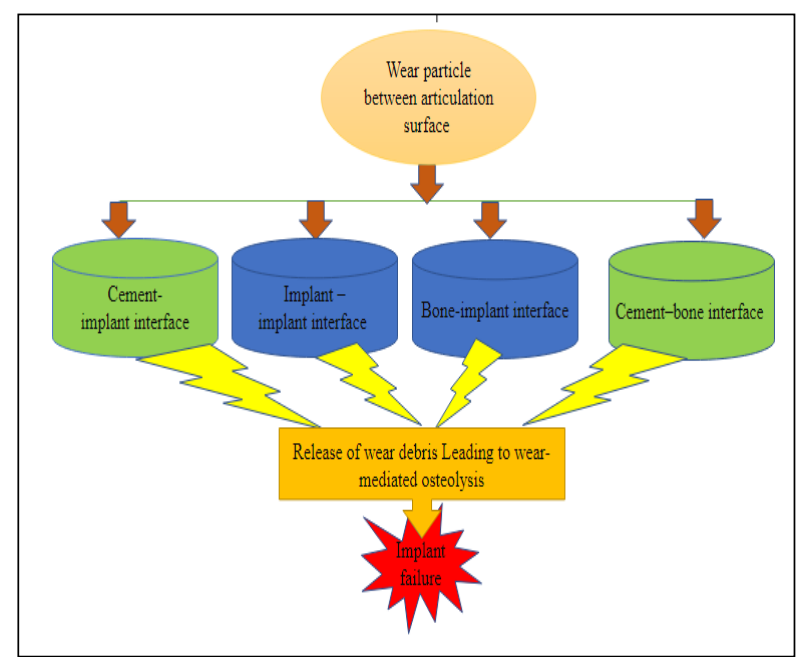

Fig.4. Schematic representation of formation and release of wear particles in the periprosthetic area.

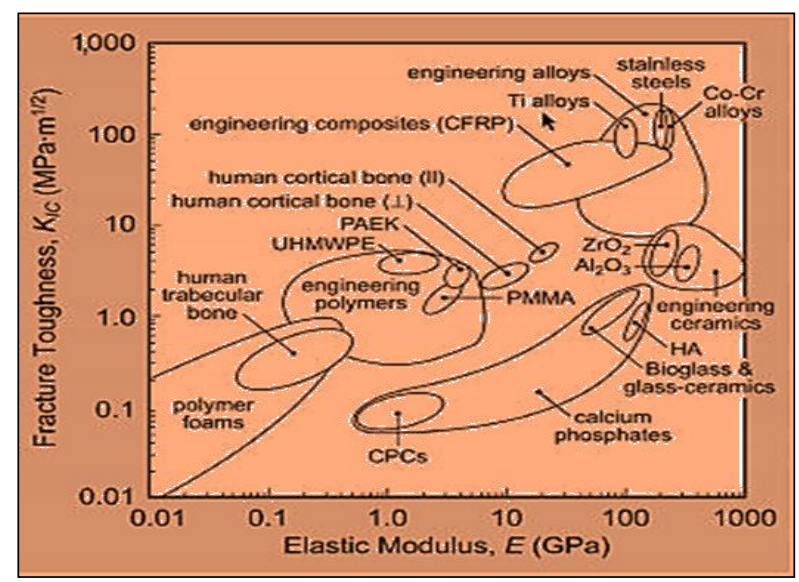

Fig.5. Bubble chart showing elastic modulus and fracture toughness of bone tissue compared to biomaterials [20].

\subsubsection{UHMWPE/HAP Bio-Nanocomposite:}

Due to the rising need for adequate bone substitutes, UHMWPE/HAP composites and nanocomposites are emerging as solutions to methods currently used. UHMWPE gives great mechanical properties, and HAP gives more prominent coordination between the bone tissue and the insert. However, $\mathrm{HA}$ is an osteoconductive material, allowing bone growth, establishing chemical bonds with bone tissue without affecting any local or systemic toxicity, swelling, or reaction to an external body. When a HAP-containing material is implanted, a layer of carbonated apatite forms on its surface, aiding the implant's bonding with living tissue and resulting in rapid stabilization and superior fixing of the implant's surrounding tissues. [24]. UHMWPE's viscosity (high obstructs its preparation. A few techniques for preparing) UHMWPE/HAP uses twin-screw extrusion, compression molding, and ball milling. Thus, mixtures' properties will mirror the homogeneous scattering of HA particles in UHMWPE. Fang et al. [25] determined the effect of paraffin oil swelling on preparing UHMWPE/nano-HA nanocomposites. They added UHMWPE powder supplemented by paraffin oil into the ball-milled nano-HA fillers and ethanol, followed by oil extraction and hot pressing. They pointed out that dealing with milling and swelling had considerably enhanced the composite stiffness, with an $85 \%$ (approx.) along with modulus.

\subsubsection{UHMWPE /Graphene Bio-Nanocomposite:}

Bhattacharyya1 et al. [7] determined that graphene as a stabilizer for UHMWPE increases its tensile strength and creep resistance. Sun er et al. [26] investigated the ability of ball milling (speed variant) as a manufacturing tool for UHMWPE/GO composites synthesis. This approach was seen to be promising due to the efficient dispersion of GO sheets into the UHMWPE matrix, which will lead to increased wear resistance. Colak et al. [27] developed RGO by green synthesis with vitamin C. The effect of RGO filler material on tribological performances under distilled water lubrication. Wear resistance property is magnified and composite with 0.7 $\mathrm{wt} \%$ (RGO) optimum properties. Kang et al. [28] investigated the osteogenic response of RGO Coating. This study used the meniscus-dragging deposition (MDD) approach for uniform RGO coating to fabricate RGO-Ti substrate for orthopedic and dental implant applications. Graziano et al.[29] fabricated HDPE and GO through melt blending and solvent response and examined the material properties. When compared to HDPE and HDPE-GO, HDPE-RFGO (solvent mixture) showed an improvement in thermal stability, mechanical properties and crystallization conduct, demonstrating that uniform scattering of RFGO in the matrix framework, as well as solid associations between them, tends to result in encouraging stress transfer, delayed thermal degradation, and more proficient nucleating impact in prompting crystal development of HDPE.

\subsubsection{UHMWPE /MWCNT/AL2O3 Bio- Nanocomposite:}

Dabees et al. [30] performed two sets of experiments to produce HDPE/MWCNT composite and $\mathrm{HDPE} / \mathrm{Al}_{2} \mathrm{O}_{3} / \mathrm{MWCNT}$ composite in a different composition. MWCNT improves hardness and elastic modulus in HDPE. Composite with $0.6 \%$ MWCNT and 2.4\% Al2O3 improves mechanical properties compared to 3 and $5 \%$ MWCNTs. TGA of the developed nanocomposite demonstrates enhanced crystallization up to $6 \%$ after adding MWCNT to HDPE. Also, with 
$5 \%$ MWCNT, moisture absorption was reduced to $90 \%$. Cytotoxic activity $<20 \%$ was shown by A12O3/MWCNT with HDPE, making it acceptable for medical use. Thus, developed material appeared to be candidate material in artificial joints development. Fig.6 demonstrates SEM and TEM analysis of an HDPE/MWCNT hybrid composite containing 5\% MWCNT.

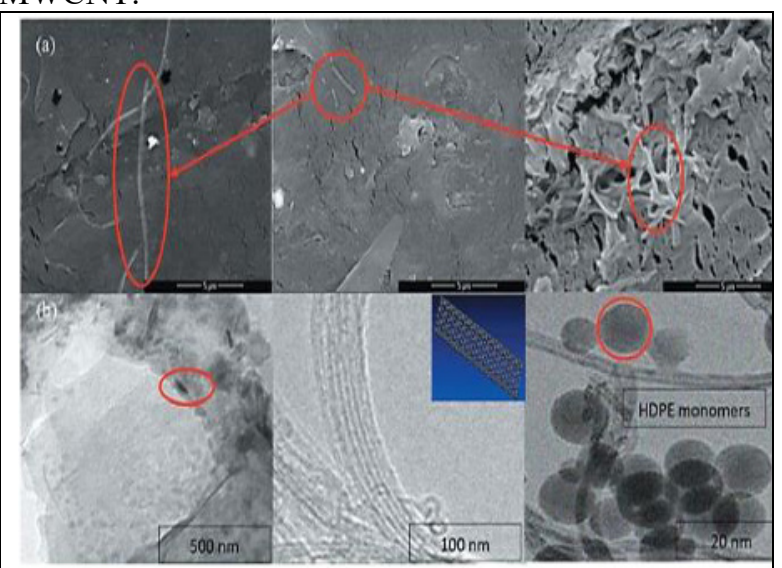

Fig.6. (a) SEM of an hybrid composite(HDPE/( 5\%) MWCNT (b) TEM analysis.

\subsubsection{UHMWPE /ZIRCONIUM Bio- Nanocomposite:}

Good et al. [31] compared polyethylene wear (nonirradiated and heavily crosslink) with $\mathrm{OxZr}$ and $\mathrm{CoCr}$ head. In smooth and rough conditions, the wear was up to 15 times less, and up to 4 times fewer fragments were generated. Salari et al. [32] analyzed the nano- zirconia in different compositions by mixing them with UHMWPE and HAP matrix. Mechanical and wear analysis was performed on the formed composite, and improvement in tensile and wear properties was noted $10 \mathrm{wt} . \%$ zirconia and $10 \mathrm{wt} . \%$ Hap sample describe $45 \%$ expand in yield strength, and friction coefficient was reduced to $64 \%$ with good biocompatibility. Plumlee et al. [33] used the zirconium as reinforcement in UHMWPE with positive impacts. Compression-molded UHMWPE with micro-zirconium particles (20 wt.\%) was investigated for Wear and impact strength. This composite displayed a massive decrease in wear relative to unfilled polymer, thus retaining impact toughness.

The shape, scale, type, and dispersion of filler materials used in UHMWPE composites determine their wear behavior. Table 2 depicts a comparison of the tribological and mechanical properties of UHMWPE.

Table 2. Impact of nanoparticle or fiber reinforcement

\begin{tabular}{|c|c|c|c|c|}
\hline $\begin{array}{l}\text { Reinforc } \\
\text { ement }\end{array}$ & $\begin{array}{l}\text { Size / } \\
\text { amount }\end{array}$ & $\begin{array}{l}\text { Mechanic } \\
\text { al } \\
\text { properties }\end{array}$ & $\begin{array}{c}\text { Tribologic } \\
\text { al } \\
\text { properties }\end{array}$ & Ref. \\
\hline $\begin{array}{l}\text { Polyethy } \\
\text { lene } \\
\text { glycol }\end{array}$ & $\begin{array}{l}\text { Optimu } \\
\mathrm{m} \\
\text { UHMW } \\
\mathrm{PE} \\
(60) / \mathrm{PE} \\
\mathrm{G}(40)\end{array}$ & $\begin{array}{l}\text { Flexural } \\
\text { strength: } \\
79.8 \% \text { \& } \\
\text { Modulus:7 } \\
7.5 \% \text { ) }\end{array}$ & $\begin{array}{l}\text { Shear } \\
\text { viscosity } \\
(33.3 \%) \\
\text { Loss of } \\
\text { modulus- } \\
(68 \%) \\
\text { Storage } \\
\text { Modulus- } \\
(25.5 \%)\end{array}$ & [34] \\
\hline
\end{tabular}

\begin{tabular}{|c|c|c|c|c|}
\hline $\begin{array}{l}\text { CNTs \& } \\
\text { copper } \\
\text { nanopar } \\
\text { ticles (n- } \\
\text { Cu) }\end{array}$ & $\begin{array}{l}\text { Optimu } \\
\text { m }(0.1 \\
\text { and } 0.5 \\
\text { wt. } \%)\end{array}$ & & $\begin{array}{l}\text { Abrasive } \\
\text { wear } \\
\text { decreases }\end{array}$ & [35] \\
\hline $\begin{array}{l}\text { High- } \\
\text { density } \\
\text { polyethy } \\
\text { lene } \\
\text { (HDPE) }\end{array}$ & $\begin{array}{l}\text { wt.\% } \\
(20,40, \\
50, \\
60 \& 80 \\
\text { Optimu } \\
\text { m wt.\% } \\
(50)\end{array}$ & $\begin{array}{l}\text { Breaking } \\
\text { strain. } \\
(380 \%) \\
\text { Tensile } \\
\text { strength } \\
\text { and } \\
\text { Tensile } \\
\text { yield } \\
\text { stress } \\
(69.5 \% \\
\text { and } \\
86.3 \%) \\
\text { resp. }\end{array}$ & & [36] \\
\hline $\begin{array}{l}\text { HDPE/ } \\
\text { UHMW } \\
\text { PE/modi } \\
\text { fied } \\
\text { GO }\end{array}$ & $\begin{array}{l}\text { Optimu } \\
\text { m } \\
\text { HDPE } \\
(60 \\
\text { wt.\%)/ } \\
\text { UHMW } \\
\text { PE(40 } \\
\text { wt.\%), } \\
\text { reinforce } \\
\text { d with } 1 \\
\text { wt.\% } \\
\text { mGO }\end{array}$ & $\begin{array}{l}\text { Tensile } \\
\text { strength } \\
120 \%(\uparrow) \\
\text { and elastic } \\
\text { modulus } \\
\text { by } 40 \% \\
(\uparrow)\end{array}$ & & [37] \\
\hline Zeolite & $\begin{array}{l}\text { wt.\% (10 } \\
-20) \\
\text { Optimu } \\
\text { m } \\
\text { wt.\%(10 } \\
\text { ) }\end{array}$ & $\begin{array}{l}\text { Strength- } \\
125 \% \\
\text { Impact } \\
\text { Elongation } \\
-89.2 \% \\
\text { Modulus- } \\
131 \% \\
\text { Tensile } \\
\text { Strength- } \\
89 \%\end{array}$ & $\begin{array}{l}\text { Volume } \\
\text { loss (80- } \\
85 \%) \\
\text { approx. } \\
\text { COF } \\
(80-90 \%) \\
\text { approx. }\end{array}$ & [38] \\
\hline $\begin{array}{l}\text { Hydrox } \\
\text { yapatite } \\
\text { (HA) }\end{array}$ & $\begin{array}{l}\text { wt.\% } \\
(4.7-22 . \\
) \\
\text { Optimu } \\
\text { m wt.\% } \\
(22.8)\end{array}$ & $\begin{array}{l}\text { Elongation } \\
\text { at break- } \\
74 \% \\
\text { Yield } \\
\text { strength- } \\
104 \% \\
\text { Modulus- } \\
888 \% \\
\end{array}$ & & [39] \\
\hline $\begin{array}{l}\text { Carbon } \\
\text { Nanotub } \\
\text { es }\end{array}$ & $\begin{array}{l}\text { wt. } \% \\
(0.1, \\
0.45 \& \\
0.5), \\
\text { Optimu } \\
\text { m wt.\% } \\
(0.1)\end{array}$ & $\begin{array}{l}\text { Micro } \\
\text { Hardness- } \\
100.2 \%\end{array}$ & $\begin{array}{l}\text { Wear rate- } \\
118 \%\end{array}$ & [40] \\
\hline $\begin{array}{l}\text { Carbon } \\
\text { Fibers }\end{array}$ & $\begin{array}{l}\text { Optimu } \\
\text { m- } \\
(\mathrm{CF} / \mathrm{UF} / \\
\mathrm{CF}- \\
2 / 12 / 2)\end{array}$ & $\begin{array}{l}\text { Flexural } \\
\text { Strength } \\
\text { and } \\
\text { Modulus } \\
(509 \%) \\
\text { and } \\
(284 \%) \\
\text { resp. } \\
\text { Ballistic } \\
\text { Limit- } \\
(91 \%) \\
\end{array}$ & & [41] \\
\hline
\end{tabular}




\begin{tabular}{|c|c|c|c|c|}
\hline $\begin{array}{l}\text { Nano } \\
\text { clay }\end{array}$ & $\begin{array}{l}\text { wt.\% } \\
(0.5,1.5 \\
\& 3) \\
\text { Optimu } \\
\text { m wt.\% } \\
(1.5) \\
\end{array}$ & $\begin{array}{l}\text { Hardness- } \\
(134 \%)\end{array}$ & $\begin{array}{l}\text { Wear Life- } \\
\text { Over } \\
10,000 \\
\text { cycles }\end{array}$ & [42] \\
\hline $\begin{array}{l}\text { MWCN } \\
\text { Ts }\end{array}$ & $\begin{array}{l}\text { wt.\% } \\
(0.1,0.5 \\
\& 1) \\
\text { Optimu } \\
\text { m } \\
\text { wt.\%(1) } \\
\end{array}$ & & $\begin{array}{l}\text { Wear Rate- } \\
(74 \%)\end{array}$ & [43] \\
\hline $\begin{array}{l}\text { Graphe } \\
\text { ne }\end{array}$ & $\begin{array}{l}\text { wt.\% } \\
(0.5-3) \\
\text { Optimu } \\
\text { m wt.\%- } \\
(0.7)\end{array}$ & $\begin{array}{l}\text { Linear } \\
\text { weight } \\
\text { loss temp } \\
(102 \%) \\
\text { Toughness } \\
(55 \%) \\
\text { Micro- } \\
\text { hardness- } \\
(110 \%) \\
\end{array}$ & & [44] \\
\hline $\begin{array}{l}\text { Graphe } \\
\text { ne } \\
\text { nanopla } \\
\text { telets }\end{array}$ & $\begin{array}{l}\text { wt. } \% \\
(0.1 \text { to } \\
10) \\
\text { Optimu } \\
\text { m wt.\% } \\
(0.5)\end{array}$ & $\begin{array}{l}\text { Tensile } \\
\text { strength- } \\
(75 \%) \\
\text { Elastic } \\
\text { modulus- } \\
(130 \% \\
) \text { Yield } \\
\text { strength } \\
\text { and } \\
\text { Toughness } \\
(76 \% \text { and } \\
113 \%) \\
\text { resp. }\end{array}$ & & [45] \\
\hline Aramid & $\begin{array}{l}\text { wt.\% (2- } \\
5)\end{array}$ & $\begin{array}{l}700 \% \\
\text { Hardness }\end{array}$ & $\begin{array}{l}\text { COF } \\
(107 \%) \\
\text { Specific } \\
\text { wear (60\%) } \\
\text { Roughness } \\
(172 \%)\end{array}$ & [46] \\
\hline $\begin{array}{l}\text { Nano } \\
\text { ZnO }\end{array}$ & $\begin{array}{l}\text { wt.\% } \\
(5-20) \\
\text { Optimu } \\
\text { m wt.\% } \\
(10) \\
\end{array}$ & & $\begin{array}{l}\text { COF } \\
(100 \%) \\
\text { Wight loss } \\
(\mathrm{mg}) \\
58.5 \% \text { \& } \\
\end{array}$ & [47] \\
\hline $\begin{array}{l}\mathrm{SiO}_{2} \\
\text { nano- } \\
\text { spheres }\end{array}$ & $\begin{array}{l}\text { wt.\% } \\
(0.5,1 \& \\
2,4) \\
\\
\text { Optimu } \\
\text { m wt.\% } \\
\text { (1) } \\
\end{array}$ & & & [48] \\
\hline $\begin{array}{l}\text { Nano- } \\
\text { diamon } \\
\text { d }\end{array}$ & $\begin{array}{l}\text { wt.\% } \\
(0.5,1 \& \\
2) \\
30-40 \\
\text { nm } \\
\text { Optimu } \\
\text { m-1 } \\
\text { wt.\% }\end{array}$ & $\begin{array}{l}\mu- \\
\text { Hardness- } \\
97.6 \% \text {, } \\
\text { Yield } \\
\text { Stress-No } \\
\text { change }\end{array}$ & $\begin{array}{l}\text { Wear rate- } \\
(28 \%), \\
\text { COF-(76\%) }\end{array}$ & [49] \\
\hline $\begin{array}{l}\text { Nano- } \\
\text { diamon } \\
\text { d } \\
\text { (NDs) }\end{array}$ & $\begin{array}{l}\mathrm{ND}(0.1, \\
0.3,0.5, \\
\text { and } \\
0.7 \text { wt. } \\
\%) \\
\text { Optimu } \\
\mathrm{m} \\
\text { loading }\end{array}$ & $\begin{array}{l}\text { Modulus } \\
(\uparrow) 15 \% \text {, } \\
\text { yield } \\
\text { stress } \\
(\uparrow) 31 \% \text {, } \\
\text { toughness } \\
(49.6 \%) \\
\text { and } \\
\text { fracture }\end{array}$ & & [50] \\
\hline
\end{tabular}

\begin{tabular}{|l|l|l|l|l|}
\hline & $\begin{array}{l}(0.5 \text { wt. } \\
\%)\end{array}$ & $\begin{array}{l}\text { stress } \\
(30 \%) \\
\text { respectivel } \\
\text { y }\end{array}$ & & \\
\hline
\end{tabular}

Despite the considerable improvements made to UHMWPE tribological performance, a few difficulties remain:

a) Applications involving bearings: Some of the primary problems for the adaptability of UHMWPE to demanding tribological uses such as mechanical bearings are to raise their load-bearing capacity and improve their thermal stability. As a result, different individual nanofillers or combinations can be investigated further to resolve the obstacles mentioned above and improve the overall applicability of UHMWPE to such application areas.

b) Applications in biomedical: Using a bulk form of UHMWPE for biomedical purposes may cause wear debris particles, leading to various issues within the human body. The above difficulty can be overcome by experimenting with multiple fillers, surface treatments, etc.

Apart from the application mentioned above, UHMWPE is in the field of Packaging machinery parts, bulletproof armor design, food industries machinery, dock fenders, truck bed liners, etc.[51]-[53]

\section{Concluding Remarks}

The proposed up-to-date strategies highlight the emerging trends in polymeric biomaterials and their application in prosthesis implants. These findings demonstrate a promising aspect in the development of new cutting-edge nanotechnology-based improved biomaterials. The results of the proposed critical review are as follows:

$>$ Nanoparticles are promising for biopolymer improvement in biocompatibility, cell adhesion, and growth, adding antibacterial character. The genotoxicity and cell oxidation must be carefully evaluated.

$>$ Few studies are reported with graphene (GO/RGO/GNP) nanoparticles and UHMWPE ; it needs to be worked out to estimate the adequate $\mathrm{wt} \%$ for tailor-made applications in different biomedical materials.

> Nano particles such as $\mathrm{CNTs}, \mathrm{Zro}_{2}$ NDs $\&$ RGO needed to be worked out to produce hybrid composites made by bi-filler addition to get the tremendous benefits with sustainable composite material for a larger implant span.

$>$ The possibility of developing hybrid composites made by bi-filler addition to get maximum benefits must be worked out to produce sustainable composite material for a larger implant span.

This article highlights the rôle of nanomaterials to improve the interface during UHMWPE composite at 
the molecular level. The involvement of nanoreinforcement has achieved good opportunities for developing new advanced technologies bio-materials with longer life and better capabilities. Also, to understand the load transfer process across the interface between nanoparticles and polymer matrix, intervention through advanced characterization methods and stimulation (interface modeling) is highly required. Further progress by adding different types of nanoparticles in UHMWPE biomaterials could be a major step for several exciting applications. It could become a cost-effective and easy to fabricate composite material having a wide variety of applications in the manufacturing of polymer composites.

\section{References:}

1. Welch, G. , Bishop, G. In Pract. 7, 1 (2006).

2. De Santis, R., Gloria, A. , Ambrosio, L. Composite materials for hip joint prostheses. Biomedical Composites (Elsevier Ltd., 2017).

3. Maksimkin, A. V., Kaloshkin, S. D., Tcherdyntsev, V. V., Senatov, F. S., Danilov, V. D., Inorg. Mater. Appl. Res. 3, 288 (2012).

4. Maksimkin, A. V., Kaloshkin, S. D., Tcherdyntsev, V. V., Chukov, D. I. , Stepashkin, A., Biomed. Eng. (NY). 47, 73 (2013).

5. Sonntag, R., Reinders, J., Kretzer, J. P., Acta Biomater. 8, 2434 (2012).

6. Zeman, J.,J. Mech. Behav. Biomed. Mater. 87, 30 (2018).

7. Bhattacharyya, A., Chen, S. , Zhu, M.,,Express Polym. Lett. 8, 74-84 (2014).

8. Langlois, J., Hamadouche, M., Sicot-J ,6, (2020).

9. Sobieraj, M. C. , Rimnac, C. M., J. Mech. Behav. Biomed. Mater. 2, 433 (2009).

10. Schwartsmann, C. R., Boschin, L. C., Gonçalves, R. Z., Yépez, A. K. , de Freitas Spinelli, L., Rev. Bras. Ortop. 47, 154 (2012).

11. Kurtz, S. M. UHMWPE Biomaterials Handbook: Ultra High Molecular Weight Polyethylene in Total Joint Replacement and Medical Devices: Third Edition (Elsevier Inc ,2015).

12. Birman, M. V., Noble, P. C., Conditt, M. A., Li, S. , Mathis, K. B., J. Arthroplasty ,20, 87 (2005).

13. Puértolas, J. A. , Kurtz, S. M.,J. Mech. Behav. Biomed. Mater. 39, 129 (2014).

14. Glyn-Jones, S., J. Arthroplasty 23, 337 (2008).

15. Ghalme, S. G., Mankar, A., Bhalerao, Y.,Int. J. Mater. Sci. Eng. 4, 113 (2016).

16. Scholz, R., J. Mech. Behav. Biomed. Mater. 85, 94 (2018).

17. Tsukamoto, R., Acta Orthop. 77, 505 (2006).

18. Bashyal, R. K., Eberhardt, J., Malchau, H., Semin. Arthroplasty 22, 79 (2011).

19. Pietrzak, W. S., J. Investig. Surg. 0, 1 (2019).

20. Roeder, R. K., Converse, G. L., Kane, R. J., Yue, W., Jom, 60, 38 (2008).

21. Yamamoto, K., Tateiwa, T. , Takahashi, Y., J. Orthop. Sci. 22, 384 (2017).

22. Affatato, S., Freccero, N. , Taddei, P., J. Mech. Behav. Biomed. Mater. 53, 40 (2016).
23. Chen, G., Ni, Z., Qian, S. , Zhao, Y., Ind. Lubr. Tribol. 68, 548 (2016).

24. Sadat-Shojai, M., Khorasani, M. T., DinpanahKhoshdargi, E. , Jamshidi, A., Acta Biomater. 9, 7591 (2013).

25. Fang, L., Leng, Y., Gao, P., Biomaterials 26, 3471 (2005).

26. Suñer, S. , Emami, N.,Tribol. - Mater. Surfaces Interfaces 8, 1 (2014).

27. Çolak, A., Göktaş, M., Mindivan, F., SN Appl. Sci. 2, (2020).

28. Kang, M. S., Biomater. Res. 25, 1-9 (2021).

29. Graziano, A., Jaffer, S., Sain, M., J. Polym. Eng. 39, 85 (2019).

30. Dabees, S., Kamel, B. M., Tirth, V., Elshalakny, A. B., Bioengineered 11, 679 (2020).

31. Good, V., Widding, K., Hunter, G. , Heuer, D.,Mater. Des. 26, 618 (2005).

32. Salari, M., Mohseni Taromsari, S., Bagheri, R. , Faghihi Sani, M. A., J. Mater. Sci. 54, 4259 (2019).

33. Plumlee, K., Schwartz, C. J., Wear 267, 710 (2009).

34. Li, Y., He, H., Ma, Y., Geng, Y. , Tan, J.,Adv. Ind. Eng. Polym. Res. 2, 51 (2019).

35. Suresha, B., Harshavardhan, B., Rao, A. M., Koushik, U. R., Hemanth, R., Mater. Today Proc. 27, 2169 (2019).

36. Khasraghi, S. S. , Rezaei, M., J. Thermoplast. Compos. Mater. 28, 305 (2015).

37. Bhusari, S. A., Sharma, V., Bose, S. , Basu, B., J. R. Soc. Interface 16, (2019).

38. Chang, B. P., Akil, H. M. , Nasir, R. M.,. Procedia Eng. 68, 88 (2013).

39. Fang, L., Leng, Y., Gao, P.,Biomaterials 27, 3701 (2006).

40. Liu, Y., Sinha, S. K., Wear 300, 44 (2013).

41. Zulkifli, F., Int. J. Impact Eng. 129, 119 (2019).

42. Azam, M. U., Samad, M. A.,Prog. Org. Coatings 118, 97 (2018).

43. Baena, J. C. , Peng, Z., Polym. Test. 71, 125 (2018).

44. Melk, L. , Emami, N.,Compos. Part B Eng. 146, 20 (2018).

45. Alam, F.,Mater. Sci. Eng. B Solid-State Mater. Adv. Technol. 241, 82 (2019).

46. Gürgen, S., Çelik, O. N., Kuşhan, M. C.,Compos. Part B Eng. 173, (2019).

47. Chang, B. P., Md. Akil, H. , Bt. Md. Nasir, R.,Wear 297, 1120 (2013).

48. Shi, G., Cao, Z., Yan, X., Wang, Q., Mater. Chem. Phys. 236, 121778 (2019).

49. Golchin, A., Villain, A. , Emami, N., Tribol. Int. 110, 195 (2017).

50. Dalai, N. , Sreekanth, P. S. R., J. Mech. Behav. Biomed. Mater. 116, 104327 (2021).

51. Danilova, S. N.,Polymers (Basel). 13, 1 (2021).

52. Toyen, D., Wimolmala, E., Sombatsompop, N., Markpin, T. , Saenboonruang, K., Radiat. Phys. Chem. 164, 108366 (2019).

53. Zhao, Z. N., Compos. Part B Eng. 221, 109023 (2021). 